\title{
Land-Use Planning and the Public: Is There an Optimal Degree of Civic Participation?
}

\author{
Miroslav Kopáček 마
}

check for

updates

Citation: Kopáček, M. Land-Use Planning and the Public: Is There an Optimal Degree of Civic

Participation? Land 2021, 10, 90. https://doi.org/10.3390/land10010090

Received: 21 December 2020

Accepted: 17 January 2021

Published: 19 January 2021

Publisher's Note: MDPI stays neutral with regard to jurisdictional claims in published maps and institutional affiliations.
Department of Human Geography and Regional Development, Faculty of Science, University of Ostrava, Chittussiho 10, 71000 Ostrava, Czech Republic; miroslav.kopacek@ujep.cz; Tel.: +420-475-284-912

\begin{abstract}
Civic participation has an irreplaceable role in the land-use planning process because it contributes a practical perspective to expert knowledge. This article discusses whether there is actually a level of civic participation that can be considered optimal, which would allow experts to effectively obtain information from everyday users of the territory, who have the best practical knowledge of it; experts may also gain sufficient feedback on intended developments, based on knowledge about civic participation from representatives of individual municipalities. The article also proposes measures that can promote an optimal degree of participation in the land-use planning process. The fieldwork was conducted in the form of semi-structured interviews with the mayors of municipalities with a population of up to 2000 inhabitants in selected districts of the Ústí Region (Czech Republic). The results suggest that the optimal degree of civic participation in land-use planning should have a representative extent, so it should not merely be a matter of individuals, but also one of groups of dozens of people, and such groups should encompass a balanced variety of characteristics; an optimal level of civic participation should also provide the maximum number of relevant impulses. Measures that may secure and foster an optimal degree of civic participation in land-use planning include (1) striving to avoid preferring purely voluntary participation; (2) simultaneously utilizing various tools to engage inhabitants; (3) educating inhabitants on a regular basis; and (4) consistently communicating and providing feedback, while also searching for informal means of communication and discussion.
\end{abstract}

Keywords: participation; engagement; optimal degree; land-use planning; land-use plan

\section{Introduction}

Participation is currently regarded as a major element of the planning process, as it seeks answers to questions of public interest—with the public's assistance [1]—so its application helps strengthen and advance democracy [2,3], especially aggregative democracy [4]. Participation leads to collaborative learning [3-5], which facilitates discussions between involved parties [6]. Participation also has a psychological dimension, as it supports people's need to express themselves and be part of something [7]. From a planning approach perspective, participation is the core component of "bottom-up" planning [8].

Effective and sustainable planning can rarely be achieved by expert knowledge alone, and civic participation offers a means of complementing the expert view [9]. At the same time, individual intentions should always be pre-emptively assessed to see whether participation is relevant and beneficial to the given project [10]. Participation has a positive effect on planning overall, though individual particularities will always display certain negatives as well [11]. For this reason, this article seeks to present a comprehensive evaluation of participation with regard to both positive and negative aspects in the landuse planning process, and aims to answer the primary question, contained in the paper's title, regarding whether an optimal degree of civic participation exists and can be defined. If possible, this would effectively enable experts to acquire information from everyday users of the territory, who have the best practical knowledge of it, while also gaining feedback on intended developments. 
The aim of the article is to assess whether there is an optimal level of civic participation in the land-use planning process, and if so, to define its form and typical attributes, based on knowledge about civic participation from representatives of individual municipalities. A secondary aim of the paper is to suggest suitable ways of facilitating an optimal degree of participation in the land-use planning process. The research is based on the author's fieldwork, which is supplemented by theoretical findings based on a survey of the relevant literature.

\section{Civic Participation and Land-Use Planning}

Land-use planning is a necessary instrument for the deliberate management of land and the sustainability of territorial policy [12], and participation currently has a solid tradition and is regarded as one of the core pillars of territorial policy, so much so that the term "communicative planning" is used [13]. Participation of the public is essential for obtaining local knowledge [5], which can be harnessed to improve the planning process [11,14], as it helps predict and identify areas of potential conflict in future land use [15]. If the experts (planners) understand these problems and the overall mode of operation of the given territory, they can plan effectively [16-18]. The issue is influenced by the region's historical experience with participation, which may determine the form of participation in relation to politicians and experts versus citizens and civic movements. Therefore, participation may manifest as conflict in one place and neutral cooperation elsewhere [19].

Land-use planning is a political instrument designed to ensure the sustainable development of a territory, and it is important for the involved parties to communicate and negotiate together. For this reason, the present approach to land-use planning is sometimes termed "participatory land-use planning" (PLUP) [20]. Civic participation may take various forms within the land-use planning process; some examples with regard to direct contact between citizens and experts include hearings, dialogue meetings, and workshops [21], or other types of a visual nature [22]. Participatory tools can be hard or soft [23], where "hard" tools are derived from legislation [24], such as public hearings [25], and "soft" tools have a more informal and supplementary character, such as public surveys or participatory workshops [26].

\subsection{Civic Participation: The Strengths and Positives in Land-Use Planning}

Participation brings decisions closer to those actors of territorial development [27] who are everyday users of the territory, thus helping to identify the consistency, compatibility, or potential conflict in the territory's use [28]. Civic participation is a means of applying the "know-how" of local inhabitants to the planning process [29], and it facilitates familiarity with the mode of operation and natural conditions of the given area [3], consequently enabling a higher effectiveness in decision-making [2]. Participation may also have a preventative character, as it can avoid potential future protests of citizens against the implementation of the planned intentions [30]. With more relevant parties, including inhabitants, involved in the planning process, better solutions can be found to individual problems [31], leading to greater public satisfaction with the chosen solution [2]. Civic participation also improves the overall effectiveness of planning and citizens' satisfaction with the process [32], making it more legitimate and informed [6].

If the findings obtained from the public are applied to a sufficient extent, the land-use plan and the individual decisions subsequently based off of it may benefit from a higher effectiveness and efficiency [18,33], as planning sourced solely from expert and academic perspectives is often lacking in terms of the effect [32]. Citizens may also provide basic information, and they are one of the cornerstones of a successful transformation into a smart city or village [34]; people with matching intentions and interests may also associate and form groups and coalitions [35], which may bolster local social cohesion. The ever-growing use of online technologies also offers a greater potential for public engagement [36]. 


\subsection{Civic Participation: The Weak Points and Negatives in Land-Use Planning}

Participation in land-use planning is generally required by law [23], but this often takes on a mostly pro-forma character [37], and participatory mechanisms are very weakly institutionalized [38]. This explains why, in practice, steps that reinforce participation are rarely made voluntarily, and are instead mandated by legislation [39], which merely illustrates how little importance is accorded to participation by many politicians and experts [40]. Experts generally lack sufficient skills to effectively incorporate the inhabitants' input into their land-use planning, even when they consider it valuable [37,41], yet on the other hand, they do not necessarily always respect or trust these lay opinions and observations, as most citizens do not wield expert knowledge and do not comprehensively understand the process in all its complexity [42]. Nonetheless, it is important for experts to have the ability to communicate [43], because the intentions and perspectives of experts and the public may differ drastically [44]. Another issue is the frequent absence of any methodological framework for participatory planning [45].

Local knowledge has a largely spatial character [3], which does not allow it to be applied elsewhere [46,47], while conversely, there can be no universally valid solution [18]. There is also the danger of participatory bias, in which certain groups promote their own interests [48], seeking individual benefits to the possible detriment of the territory's landuse planning, such as in the case of flood risk [49,50], as a consequence of their preference for rapid returns on investment [40]. All in all, land-use planning offers considerable potential for self-enrichment, which may also be channeled via participation-for example, when changing a property's use class (such as turning agricultural land into a building lot) - and this invites a real risk of corruption. Therefore, planning should incorporate anti-bribery measures [51].

With regard to participation, it is ill-advised to rely solely on voluntary engagement by citizens, as this does not provide comprehensive information about the territory [52]. Voluntary participation usually generates an uneven representation of individual categories of citizens - for example, young inhabitants evince minimal engagement [53] — whereas individual groups (variably classified by age or selection method) may identify different problems and define divergent preferences [52]. Therefore, if a group is not represented during the planning process, its opinions and needs are not reflected in the resulting plan. The non-participation of individual groups can lead to the plan's faulty interaction with the local environment [53], and so it is always important to involve all parties and groups based on various criteria [45], instead of only relying on voluntary, self-induced engagement [48]. In practice, the initiating entity often fails to achieve a desirable level of actual participation [39], as local governments and planners only rely on voluntary participation and do not actively seek information other ways [52].

\subsection{Challenges for Civic Participation and Land-Use Planning}

Interaction between individual citizens, their communities, and policy-makers is important [3], yet these groups often evince a lack of social cohesion, which limits the community's ability to participate [54]. Despite this, for planners, politicians, and citizens to be able to plan correctly and efficiently, they must have sufficient information about the given territory [12], and such critical information and knowledge can be obtained from the citizens, including inhabitants and owners of property [55]. With regard to participation, it is suitable to designate the relationship between planning and private ownership, which is seen as a potential threat if left unregulated, in the sense of the unproductive and uneconomic use of land [56], and this leads to the necessity of private participation [2].

For citizens to be engaged, they must be intrinsically motivated to become involved in the process [57], and the best way to secure their engagement is to induce in citizens the feeling that they own a given project (such as the municipality's territory via the land-use plan), which will lead to their greater creativity and effort [58]. However, for that to be possible, citizens must be informed about both the land-use planning process itself and their means of involvement [36]. It is important to convince the inhabitants that participation in 
the land-use planning process is a key instrument for ensuring the sustainable development of the territory [14,37], which may in turn secure good living conditions and satisfy the needs of the territory's inhabitants in the long term $[16,40]$. Primarily, it would be suitable to cultivate in citizens the sense that participation and policy co-creation is the mark of a "good citizen" [59]. At the same time, the added value of public participation must be considered [60], and there is a need to define the criteria for public participation for the purpose of evaluating the participatory tools used [8].

Local governments should be open to both traditional and new forms and instruments of public engagement [61]. A prominent current topic with regard to participation is the use of information and communication technologies [36], the potential of "Web 2.0" [52], and online instruments to boost citizens' involvement in land-use planning [62], such as public participation GIS (PPGIS), participatory GIS (PGIS), and volunteered geographic information (VGI) [52,63-65]. Online tools have added value in how they facilitate the dissemination of information, public involvement, and the accumulation of local knowledge [60], though one negative is social injustice, as not all groups of the population are able to use these instruments equally well [60]. For example, the use of social networks brings the issue closer to younger inhabitants, whereas paper questionnaires ensure a better spread of individual age groups in the surveys, but do not address the question of the respondents' different levels of education [66].

\section{Research Methodology}

The spatial scope of the research was limited to municipalities in one of the Higher Territorial Administrative Units of the Czech Republic, namely, the Ústí Region. This territory is further divided into seven districts, which are of administrative and statistical significance. The research took place in only four of these districts, located in the central and eastern parts of the Ústí Region, namely, the districts of Teplice, Ústí nad Labem, Děčín, and Litoměřice. The remaining three districts of Chomutov, Most, and Louny were not taken into account, as a relevant research sample was already assembled using the first four districts mentioned.

Specific municipalities were chosen using the stratified random sampling method [67], with the population size as the primary criterion, with an upper limit (maximum) of 2000 inhabitants and no lower limit (minimum). The selected municipalities were then approached to ascertain whether they have their own land-use plan (Czech municipalities are not obliged to have one); this ensured that the municipalities had experience with the analysed issue of land-use planning. All of the selected municipalities met this condition. As of 31 December 2018, the chosen territory contained a total of 180 municipalities with a population of up to 2000 [68]. Of these, 63 municipalities were approached with a request for an interview, which was then carried out in 24 of them (Figure 1); these constitute the case study. The request for an interview was refused in nine municipalities, mainly due to the busy schedules of local representatives, or for reasons of personal leave or a sense of having an insufficient competency to address the issue. The remaining municipalities (30) did not respond to the email request.

The fieldwork was conducted in the form of personal interviews with the mayors of the municipalities. The Czech Republic features a relatively large number of units of basic local government (municipalities), and so, especially in low-population municipalities, the mayor is often the "only employee", whose position also gives him or her a complex view of the municipality's daily operations and development; mayors also very frequently retain their office for several terms. Interviews were chosen as a research technique for efficient data collection, using a semi-structured format $[67,69]$, based on a set of pre-determined yet open questions. One advantage of this type of interview is that its semi-structured nature limits the subjective influence of the questioner and improves the potential for further analysis [67], while providing opportunities to cover issues that only appeared in the course of the interview [69]. One disadvantage is that the interviews are standardized, which can detract from their authenticity and flexibility [67]. All the interviews were 
performed by the same person to ensure that they were conducted in the same manner and maintained cohesion. The respondents were promised in advance that their words and the information they provided would be anonymized, and so, after the conclusion of the fieldwork, the individual interviews were code-numbered before being analysed. The mayors were contacted solely by email in early July 2019, and the interviews took place in the period from 24 July to 21 September 2019. In three cases, the deputy mayor replaced the mayor for the interview due to scheduling conflicts or unavailability of the latter. The duration of each interview ranged from 15 to $30 \mathrm{~min}$ and averaged $20 \mathrm{~min}$. All the interviews were conducted and analysed in Czech, with excerpts then translated into English for the purpose of this article. A summary of the respondents is given in Table 1.

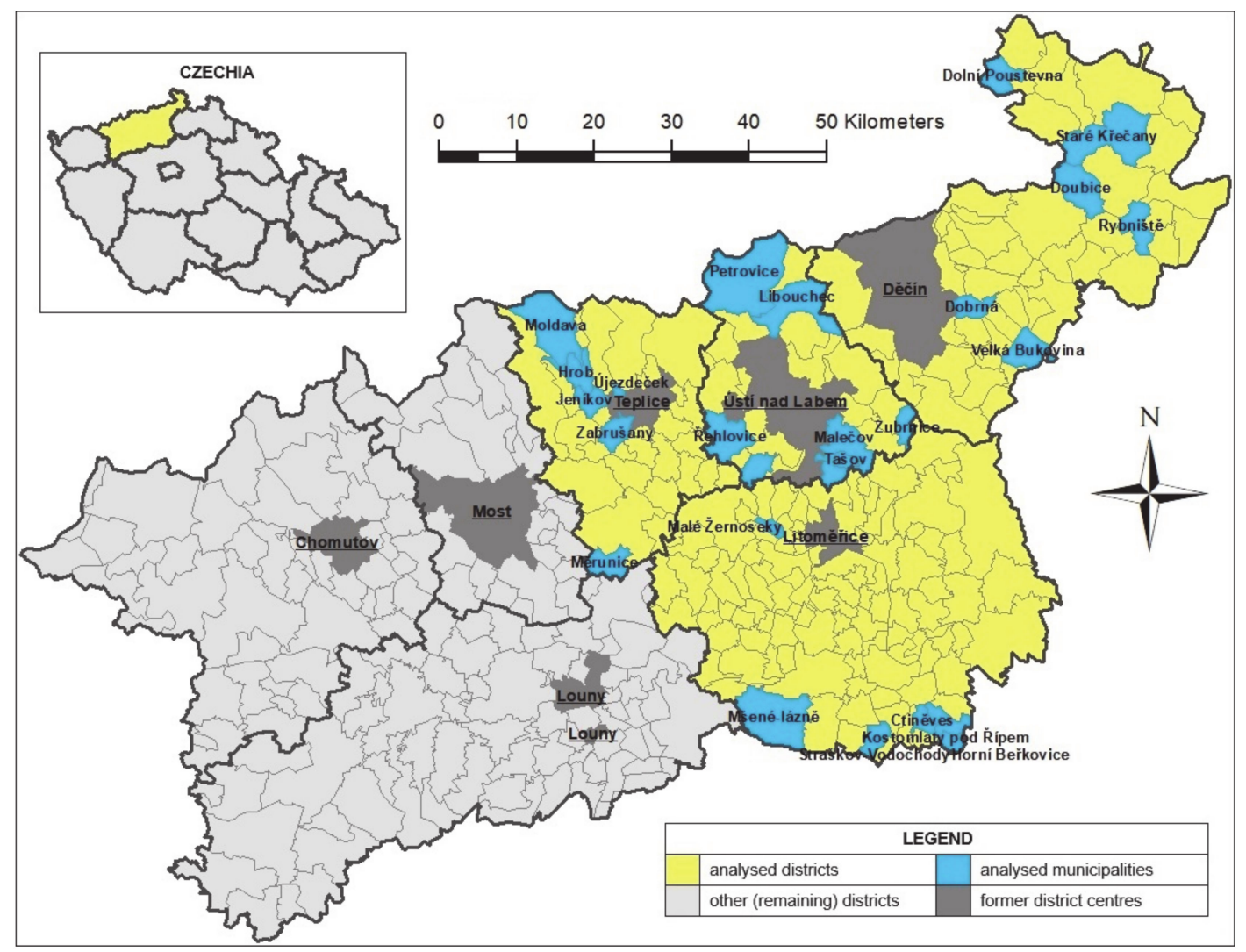

Figure 1. Map of the Ústí Region, showing districts and municipalities where the fieldwork took place.

The interview consisted of 11 questions in total, of which four were the primary focus of this analysis, being directly related to the research questions. The remaining seven queries were of secondary importance, being of an auxiliary and supplementary character. The four primary questions, which are analysed in the subsequent section of this article, were as follows:

- Can you estimate how many citizens from your municipality participated in preparing the land-use plan?

- Do you consider civic participation a necessary element of the land-use planning process? If so, in what areas is civic participation important and impactful? What is its irreplaceable role?

- Can civic participation be counterproductive or detrimental (damaging) to some aspects of the land-use planning process? If so, in which aspects or areas?

- Would land-use planning be possible without any civic involvement at all? Why? 
Table 1. Overview of the respondents.

\begin{tabular}{|c|c|c|c|c|c|c|c|}
\hline Municipality & $\begin{array}{l}\text { Population as of } \\
31 \text { December } 2018\end{array}$ & Date of Interview & $\begin{array}{c}\text { Interview } \\
\text { Provided By }\end{array}$ & Sex & Age Group & $\begin{array}{c}\text { In Office } \\
\text { (Number of } \\
\text { Terms) }\end{array}$ & Full Time \\
\hline Ctiněves & 336 & 21 September 2019 & mayor & male & $45-64$ & 3 or more & no \\
\hline Dobrná & 436 & 11 September 2019 & mayor & male & $30-44$ & 1 & yes \\
\hline Dolní Poustevna & 1732 & 7 August 2019 & deputy mayor & male & $30-44$ & 3 or more & yes \\
\hline Doubice & 112 & 31 July 2019 & mayor & male & $30-44$ & 2 & no \\
\hline Horní Beřkovice & 930 & 28 August 2019 & mayor & male & $45-64$ & 2 & yes \\
\hline Hrob & 1998 & 26 August 2019 & mayor & male & $45-64$ & 1 & yes \\
\hline Jeníkov & 856 & 4 September 2019 & mayor & female & $45-64$ & 1 & yes \\
\hline $\begin{array}{l}\text { Kostomlaty pod } \\
\text { Řípem }\end{array}$ & 440 & 4 September 2019 & mayor & male & $65+$ & 1 & no \\
\hline Libouchec & 1835 & 19 August 2019 & mayor & male & $45-64$ & 2 & yes \\
\hline Malečov & 817 & 26 August 2019 & mayor & male & $45-64$ & 3 or more & yes \\
\hline Malé Žernoseky & 719 & 29 July 2019 & mayor & male & $45-64$ & 3 or more & yes \\
\hline Měrunice & 303 & 4 September 2019 & mayor & female & $30-44$ & 3 or more & yes \\
\hline Moldava & 192 & 9 September 2019 & mayor & male & $30-44$ & 1 & yes \\
\hline Mšené Lázně & 1790 & 12 August 2019 & mayor & male & $65+$ & 2 & yes \\
\hline Petrovice & 883 & 21 August 2019 & mayor & male & $45-64$ & 3 or more & yes \\
\hline Rybniště & 665 & 22 August 2019 & deputy mayor & female & $30-44$ & 2 & yes \\
\hline Řehlovice & 1435 & 8 August 2019 & mayor & female & $30-44$ & 1 & yes \\
\hline Staré Křečany & 1260 & 2 September 2019 & mayor & male & $45-64$ & 3 or more & yes \\
\hline $\begin{array}{c}\text { Straškov- } \\
\text { Vodochody }\end{array}$ & 1070 & 19 August 2019 & mayor & male & $30-44$ & 1 & yes \\
\hline Tašov & 151 & 12 September 2019 & mayor & male & $45-64$ & 1 & no \\
\hline Újezdeček & 887 & 23 July 2019 & deputy mayor & male & $45-64$ & 3 or more & yes \\
\hline Velká Bukovina & 507 & 28 August 2019 & mayor & male & $45-64$ & 3 or more & yes \\
\hline Zabrušany & 1143 & 24 July 2019 & mayor & male & $30-44$ & 1 & yes \\
\hline Zubrnice & 239 & 7 August 2019 & mayor & male & $45-64$ & 3 or more & no \\
\hline
\end{tabular}

\section{Results}

The mayors first assessed the degree of participation in the land-use planning process in their municipality, identifying three levels of participation with regard to quantity. The first level is high, with more than $50 \%$ of the population taking part in the process, though such a high degree is rare, only being claimed by two of the 24 respondents. This was referred to as "The majority, more than half," with one mayor describing the highest possible level of participation as follows: "It seemed like everyone here was part of it, and I think it really was a $100 \%$ participation. We started off with a person requesting a change, and then we had a petition come up here with dozens of signatures protesting the architect's design." In 14 municipalities, the mayors estimated public engagement as medium, that is, including the involvement of groups amounting to dozens of inhabitants: "Participation was in the dozens. I'd say that the number of people was based on how much it involved the needs of the people who had some idea of what the land-use plan was and what it meant." In the remaining eight municipalities, the mayors described participation as low, that is, with only a few individuals engaged: "I could count the participants here on the fingers of one hand" and "... we had some requests from one or two citizens at the beginning, but no one took part afterwards." The experience varies significantly from one municipality to another, ranging from practically zero participation by citizens to practically the whole municipality becoming involved. Therefore, it is not possible to specify a typical degree of participation in low-population municipalities, and it is evident that the degree of participation depends on the particularities of each municipality.

With regard to the importance or necessity of participation for land-use planning, the mayors most frequently mentioned that involvement in the land-use planning process allowed citizens to take part in the territorial development of their municipality: " ... if I live in some place, participation allows me to join in to what will be there in the future, what is planned there..." , thus shaping the municipality and its territory in the future. Additionally, one mayor state the following: "Participation is essential, the land-use plan is a project related to the development of the municipality and its surroundings, for the future and for its long-term perspectives ... ". Participation may also introduce interesting 
ideas and proposed solutions for the territory: “ $\ldots$ as the saying goes, 'two heads are better than one,' so you can have people with some good idea and good concept for a change within the territory," and "no one is wise in all ways, so another person's opinion and another point of view can be beneficial." Participation is a major aid to both expertsplanners, who are executing the land-use planning process, and to local politicians: "You can have a solid leadership, experts for preparing the land-use plan, but there has to be participation, because the citizens see how the territory develops, and the politicians and planners can easily miss something ... ". Additionally, if citizens enter the process, the resulting land-use plan can be adjusted according to their actual needs: "You can't set the way of life here properly without the public, of course you can't please everyone, but you won't find anything out without the citizens." Last but not least, participation is an attribute of democratic society in the sense that citizens have the option to co-decide the shape of the land-use plan, thus actually impacting the future of their municipality: "It's main importance is in the citizens' right to be able to express themselves; for the citizen to be content, he should have the right to expression." All mayors responded in the affirmative to the question of whether participation is essential, and none of the respondents claimed that they considered participation to be unnecessary for land-use planning.

With regard to the negative impacts of participation, the mayors pointed to the advancement of individual intentions, which are often less than beneficial to the municipality as a whole- “ "... in those cases when the personal interests of a citizen are not beneficial to the municipality and are not in accordance with its interests and strategies" - with the only profit going to the person who made the proposal. This can stem from endeavors aimed at self-enrichment or efforts to boost the appreciation of one's property: “ . . there is always a lot of lobbying for the appreciation of properties, but I've already seen elsewhere how it was appreciated and subsequently sold." Citizens may also be too strongly focused on the short-term perspective: "People often think of their short-term purpose, but they don't see further ahead. It's hard to explain to them that everything will be completely different in a few years' time." Another potential factor is a bad grasp of what land-use planning actually is and how it works: " ... sometimes the ignorance of the fact that the land-use plan deals with the municipality as a whole and not with individual ownership pleas; most people don't realise that and only try to protect their own interests." Participation can also easily lead to delays: “ . . . for instance, if you don't satisfy someone's demands, he can appeal and protest, and that can make the whole process take longer." Participatory tools can also be used negatively to create obstructions that do not even have to be related to the issue of land-use planning, but can merely be abused for the purpose of advancing someone's interests in other matters and for gaining attention: “ . . if someone abuses the option of participation and there is no justification to it, or if they just block something from their own one-sided perspective ... one person can block the development of the whole municipality." Public involvement can also introduce a number of unrealistic demands for changes to the territory and its facilities, or foster resistance to necessary limitations: "... so we all want to have water, gas, electricity everywhere, possibly other things for a good quality of living, but on the other hand no one wants any kind of limitations.". Furthermore, a high level of engagement can aggravate emotions, leading to escalated tensions in negotiations and consequently impacting the whole process of land-use planning: " . . it happens that if we have a work meeting where emotions get out of hand, the problem is escalated, and that can influence all the participants of course ... from my own experience, I know that it is difficult to calm the situation, and things can go against the public interest." Only two of the interviewed mayors reckoned that there was no negative side to participation.

Finally, the mayors were questioned about the possibility of completely removing civic participation from the land-use planning process. This option was categorically refused by two thirds of all mayors, who argued that the land-use plan is an instrument that will influence the future operations of the municipality: " ... it is a document which we will be working with here for as much as twenty years, and so I reckon it is important to have the 
citizens involved." They also mentioned that participation is a feature of democracy and "bottom-up" planning: " . . if we excluded society, we'd be going back several decades to Socialist times ... ". They noted that the plan impacted both council property-“... council land are property of the council, and so every citizen of the municipality has the right to voice their opinion ... "- and the private property of individual inhabitants-" ... you can't do it without participation because with regard to the inhabitants it often affects their ownership rights." Some of the mayors acknowledged that land-use planning could be conducted without public involvement, as a purely expert endeavor, but they immediately countered that this would not benefit the overall quality of the plan: " ... I guess you could do it without the people, but that would be wrong ... the land-use plan serves the citizens, and so everyone should have the option to have their say." One mayor declared that the exclusion of citizens would only be possible if " . . the plan was being made only for the needs of the council and council land and in no way affected private property." All in all, it can be stated that none of the mayors categorically claimed that it would be possible to exclude the public from the land-use planning process. When some of them did admit this as a possibility, they subsequently added that it would have a negative impact on the planning, or they stipulated specific conditions that would be required. The quantified responses in individual categories are summarized in Table 2.

Table 2. Quantified categorization of responses to the four main research questions.

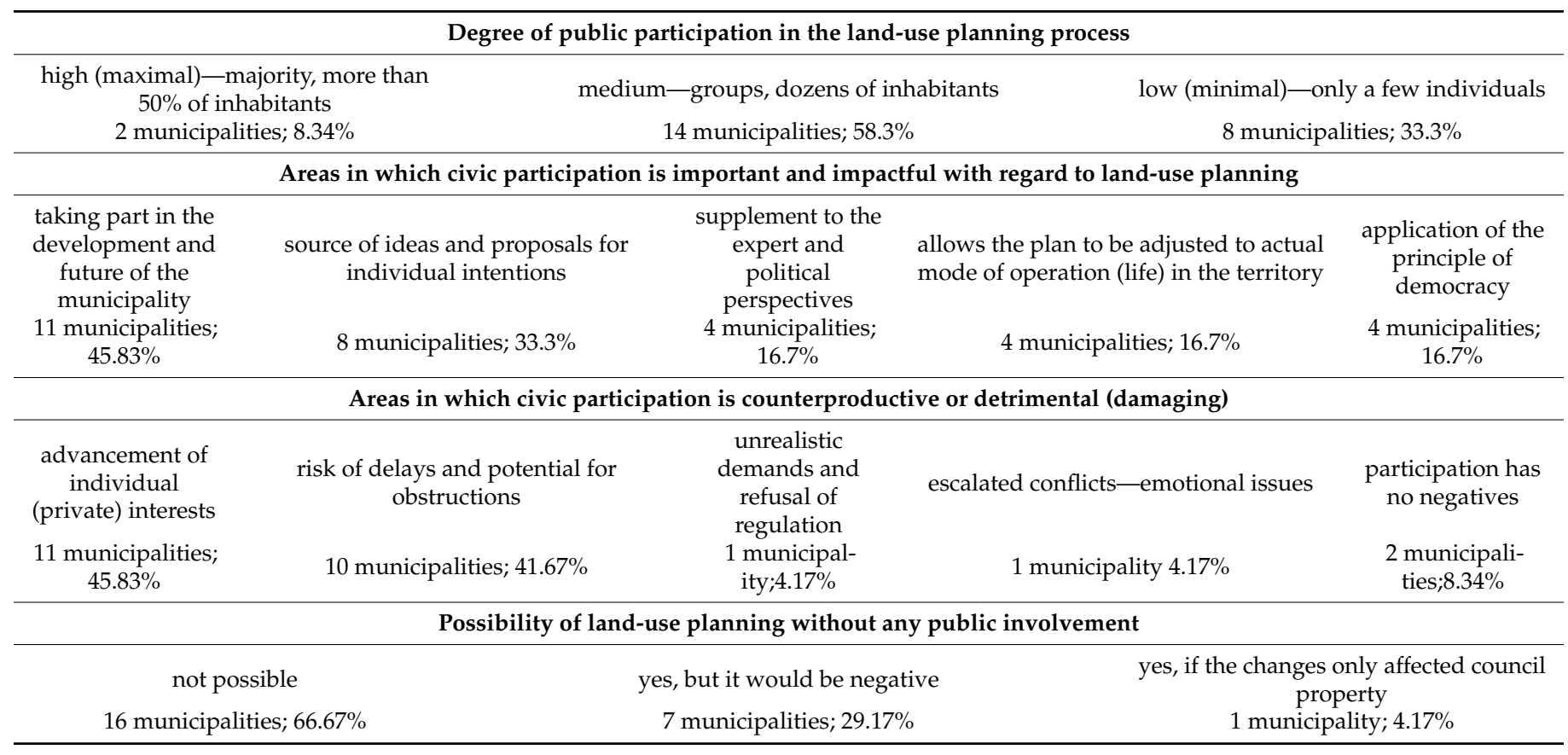

The results can be summarized in such a way that civic participation provides space for commenting on the planned intentions, which might also result in an intervention that regulates the elaboration of a land-use plan in the place where residents live and whose lives are connected with it. It is beneficial if there are presentations of different, and even very different, opinions, because the presentation of a different opinion, which may be a different view of the matter, can help to form a better final solution. At the same time, it is possible to prevent the fact that, after the approval of the land-use plan, it would not be possible to implement the intentions (usually construction) that people would like because the land-use plan is set differently. Alternatively, some residents (usually older) may provide a retrospective view of how certain things used to work within the municipality before, and the municipality may return to this in some way, in a regime that is adapted to current conditions. By analogy, residents who previously lived elsewhere (at least temporarily) can bring insight and experience from another place to the planning 
process. Social control is also very important as it can cover the shortcomings that may arise. Such shortcomings might be missed by experienced professionals, in spite of good management of the municipality, because they do not have personal experience with (even minor) problems faced by everyday users of the place, while municipality management may suffer from the so-called operational blindness. Last but not least, civic participation is an important element of democracy, as citizens have the right to engage in both their own intentions and lands, as well as in the area of public intentions and lands.

\section{Discussion}

The research confirmed that participation in the land-use planning process helps identify areas where there is a risk of potential conflict in the use of the territory [28]. At the same time, it confirmed that every participatory tool has negative effects [11], as municipal authorities frequently come up against participatory bias [48] when individuals or groups advance their own interests: “ ... this was mainly those citizens who somehow wanted to change the class of their property." If there are many such proposals, it can negatively impact the process by delaying it considerably. However, if the citizens' suggestions are factual, it is an example of positive engagement, which allows the citizens to increase their awareness of land-use planning and is conducive to collaborative education [3-5]. Citizen proposals that are denied pose a certain risk, however, as " ... those people feel that their needs weren't heard out, so then they turn to the other side, which can reflect negatively on to the next phase of planning," so it is important to communicate with citizens [13]; experts must thus be able to negotiate [43]. However, even denied applications are valuable, as the issues at hand may be properly discussed during the preparation of the land-use plan, consequently avoiding later protests of citizens dissatisfied with the planned intentions of their local government [30]. Furthermore, even rejected proposals may bring about synergic effects. If the citizens' suggestions are accepted, it generally leads to a greater level of contentment with the solutions applied by the land-use plan [2,58]. It is also important to evaluate whether participation is relevant and beneficial to a given intention [10], as this might not always be the case, for example, with regard to hard infrastructure: “ ... that is then the task of experts and us as the municipal authority, to what extent we set the participation and how the information is used". This involves the positive factor of facilitating discussion between the involved parties [6] and of disseminating information about land-use planning, as citizens are only able to plan effectively and correctly if they are sufficiently informed about the given territory [12].

The research did not confirm that participation in land-use planning in the analysed municipalities was of a merely pro-forma character [37] or that its importance was underestimated by politicians and experts: [40] “ . . . you can't just have the outside perspective ... ". On the other hand, it was confirmed that participatory mechanisms are institutionalized to a lesser degree than would be suitable [38], which is caused, among other factors, by the absence of methodological frameworks that would support participation in the planning process: [45] " ... so then it's up to the council to get it out among the people and for them to realise that it's part of the development of the municipality". In relation to this point, some of the municipalities recognized their limitations: " ... we lagged behind in our efforts to spread among the people how important the plan is and what it means." It is a considerable challenge for both local authorities and experts to take the proposals of citizens into account and implement them where applicable [37,41]: " . . the contracting authority should somehow come to terms with the material considerations, so the opinions of those people are taken seriously and properly assessed." One problematic area with untapped potential is that municipalities generally rely solely on voluntary participation and do not actively seek information by other means [52], although it can be seen as positive that local governments seek informal negotiations and channels for informing about land-use planning, for example, in the form of local bulletins, informal work meetings, or the municipal broadcast. 
An important issue that would facilitate the definition of the optimal level of civic participation would be the identification of factors that influence the level of public involvement, both positively and negatively. The stimulus for involvement in land-use planning is often some personal benefit, which relates to the effort to promote one's interest, or to evaluate one's property [23]. Therefore, it is important to look for ways to strengthen participation in matters concerning the municipality as a whole. Since something can be created or changed through participation, it is important that it also functions as a social control [70]. It is likely that the overall level of public involvement is significantly influenced by the social factors that determine how a society operates. If there is a low level of participation in the municipality for a long time and a general lack of interest in public affairs, then this state can become a natural state of the place. Closely related to this is collaborative learning [3-5], which can work for an individual in such a way that if people around them are interested in the matter, they will also be interested in it as well, because it is probably important. Of course, the whole thing can work the other way around-if no one around an individual shows interest in something, it is normal and the individual will not behave differently. This is associated with collective action [71] and the ability to cooperate in the community [35], both of which are further linked to social cohesion [54,72]. However, it would be difficult to find ways to do this, especially for municipalities where interest in public affairs is traditionally small, and a possible solution may be to profile a leader [73]. This individual would be the main leader for the issue and would be able to attract other residents and arouse interest in the matter at hand. Ideally, the role of the leader would be performed by the mayor or another important representative of the municipality.

The combination of traditional and modern tools is suitable for strengthening civic participation. It does not only have to involve the usual simplistic view that traditional tools are for the elderly and modern tools are for the young, as it is a matter of allowing everyone to choose what suits them. As a result, the citizens will feel comfortable using the tool and they can be expected to provide sufficient feedback within their individual possibilities. However, it is important to look for ways to suppress participatory bias throughout the process $[48,51]$, because, if the level of participation is low and only those who want to achieve something and pursue their individual intention are involved, it can be very negative for the community. In addition, it is important not to rely on the voluntary participation of citizens [52], but to really use the knowledge from the public, not just to encourage participation, but also to create opportunities for involvement [70]. The municipality can also use the so-called web 2.0 for obtaining observations [52], which is easily accessible with the current massive development of social networks, so the municipality can continuously monitor feedback and problems. However, especially in small municipalities, it can be problematic to allocate personnel capacities to this activity.

\section{Conclusions}

In the field of land-use planning, civic participation provides space for residents to be significantly involved, but engagement requires social cohesion and its strengthening [72]. Residents can be involved in terms of their own individual intentions, for example, if they want to change the usability of land so that they can build what they plan. Additionally, they can influence projects in their immediate vicinity that may affect their property, as well as general and complex intentions, which relate to a vision for the future in the sense of "where we are and where we are going", and in this respect, a plurality of opinions is important. The participation of citizens in the vision for the future, which will be ensured by the appropriate development of the land-use plan, is suitable due to the fact that citizens thus become participants in the project, which, from a territorial point of view, will greatly affect the functioning of the municipality in the future. On the positive side of civic participation, citizens can "build their place" through it, and if they identify with the land-use plan and adopt it as their own, they are likely to be more inclined to be satisfied with it. However, in order for this to work, it has been confirmed that it is usually necessary 
to take collective action and take steps towards social learning [71], and the profiling and follow-up of the leader (Lamker) can be a significant driving force in this direction [73]. Among other things, civic participation is important as a source of observations and ideas for individual intentions, while social control can also take place [70].

Civic participation is a major component of the land-use planning process, which is generally executed by experts via a political contracting authority. Civic participation has an irreplaceable role in supplementing expert knowledge and planning [9] with the "know-how" of local inhabitants [29]. The optimal degree of civic participation in landuse planning cannot be defined in a universally applicable manner, but it is possible to describe a number of its typical basic features. An optimal degree of civic participation (1) should constitute a representative sample of the population that inhabits the given territory-individuals are not enough, whilst a 50\% or higher level of involvement is not completely necessary, but groups of dozens of people may be sufficient if (2) these groups are well balanced and represent various population segments (young $X$ old; employees $X$ entrepreneurs; healthy X ill, etc.). Additionally, these groups may sufficient if (3) they bring relevant proposals from the citizens, which can be and are accepted, but also other impulses that are not or cannot be satisfied, and if they also allow individual citizens or groups to express themselves and enter into debate, which promotes awareness of the issue and facilitates collaborative education [3-5], thus providing the municipality with a more educated and experienced citizenry and promoting a civil society [59] with a greater future potential for participation. However, participatory bias [48] must always be taken into account as a negative external attribute.

The recommendations that can ensure and facilitate an optimal degree of civic participation in land-use planning may be summarized in the following points.

1. Do not prefer only voluntary participation, but actively obtain information as the contracting party [52]. For example, targeted surveys that encompass all population groups and types of households should be conducted, which may identify different preferences than those of voluntary participants. Although it is very difficult to representatively assess every segment of the population in practice, every effort in that direction is beneficial and boosts diversity of knowledge;

2. Engage inhabitants with multiple instruments at once. Do not only apply those means that are mandated by law [23]. A diversity of utilized participatory tools can help increase the level of participation, as every individual or group may be better suited to something different [60]; for example, older citizens may prefer to receive information through personal contact, a municipal broadcast, or from classical (physical) official noticeboards, and they may prefer to give feedback verbally or via a paper questionnaire, whereas younger inhabitants obtain information through the internet and social networks and readily provide feedback online. Younger generations generally evince a lower degree of participation [53], and this limitation can be potentially overcome by the use of modern channels [52,65]. It is also useful to allow participants to evaluate the participatory tools they use [74];

3. Organize regular educational activities, consistently communicate, and give feedback. The municipal authority should strive to actively disseminate information regarding the importance of land-use planning and its direct impact on the future development of the municipality, regarding the various means of participation and the importance thereof, so that, in the best case scenario, the inhabitants would in effect take ownership of the planning process [58]. Furthermore, individual intentions and proposals should be consistently communicated, regardless of whether they were implemented, in order to provide participants with feedback [25];

4. Seek informal channels of communication and discussion. If it is practically possible, organize informal meetings, which may have a more relaxed atmosphere, thus gaining new impulses. Another option is to complement the use of official documents with unofficial ones which - though being merely informative-are much more accessible to the ordinary citizen. These may take on the form of brief notices on the municipality's 
website, or an article in a bulletin published by the local council, perhaps structured as an interview with the mayor or with the expert who is preparing the plan.

This research deals with the optimal level of civic participation, which should be an important element for land-use planning in terms of quality. This distinguishes the present study from most professional studies, which also deal with the topic of civic participation, as they usually address the quantitative aspect, i.e., how to strengthen public participation and gain more knowledge from the public for land-use planning. However, they almost never offer solutions for producing an effective participation process. Another important group of publications focuses on civic participation in terms of the positive and negative aspects of land-use planning. Further research could focus on the citizens' motivation to become involved in the land-use planning process and on identifying the factors that might boost participation, bearing in mind that [25] notes how important it is for participants to receive feedback on how their input was used, so this aspect should also be scrutinized in further detail. Moreover, considering that the scope of the research was limited to municipalities with a small population, it would suitable and beneficial to perform a comparison with larger-population municipalities and cities, or to investigate and identify the characteristic features of voluntary participants. Last but not least, this research was only based on the evaluation of municipal representatives, i.e., individual mayors, so it would be very beneficial to evaluate the optimal level of civic participation from the perspective of planners and the public, or their representatives, in other research.

Funding: The research was financially supported by the student research grant competition of the University of Ostrava for the years 2019 [SGS16/PřF/2019] and 2020 [SGS11/PřF/2020].

Institutional Review Board Statement: Not applicable.

Informed Consent Statement: Not applicable.

Data Availability Statement: The data presented in this study are available on request from the author.

Acknowledgments: The author wishes to thank the mayors of the individual municipalities for finding time to participate in the project and for sharing their experience regarding the given issue. He is also grateful to his supervisor Petr Rumpel for his expert advice and to Tomáš Ulip and Aneta Krausová for providing technical and administrative support during the fieldwork.

Conflicts of Interest: The author declares no conflict of interest.

\section{References}

1. Nabatchi, T.; Amsler, L.B. Direct Public Engagement in Local Government. Am. Rev. Public Adm. 2014, 44, 63S-88S. [CrossRef]

2. Jacquet, J.B. The Rise of "Private Participation" in the Planning of Energy Projects in the Rural United States. Soc. Nat. Resour. 2014, 28, 231-245. [CrossRef]

3. Natarajan, L. Socio-spatial learning: A case study of community knowledge in participatory spatial planning. Prog. Plan. 2017, 111, 1-23. [CrossRef]

4. Bradley, Q. The political identities of neighbourhood planning in England. Space Polity 2015, 19, 97-109. [CrossRef]

5. Elbakidze, M.; Dawson, L.; Andersson, K.; Axelsson, R.; Angelstam, P.; Stjernquist, I.; Teitelbaum, S.; Schlyter, P.; Thellbro, C. Is spatial planning a collaborative learning process? A case study from a rural-urban gradient in Sweden. Land Use Policy 2015, 48, 270-285. [CrossRef]

6. Wilker, J.; Rusche, K.; Rymsa-Fitschen, C. Improving Participation in Green Infrastructure Planning. Plan. Pract. Res. 2016, 31, 229-249. [CrossRef]

7. Sutton, A. Living the good life: A meta-analysis of authenticity, well-being and engagement. Personal. Individ. Differ. 2020, 153, 109645. [CrossRef]

8. McCall, M.K.; Dunn, C.E. Geo-information tools for participatory spatial planning: Fulfilling the criteria for 'good' governance? Geoforum 2012, 43, 81-94. [CrossRef]

9. Tennøy, A.; Hansson, L.; Lissandrello, E.; Næss, P. How planners' use and non-use of expert knowledge affect the goal achievement potential of plans: Experiences from strategic land-use and transport planning processes in three Scandinavian cities. Prog. Plan. 2016, 109, 1-32. [CrossRef]

10. Nyseth, T.; Ringholm, T.; Agger, A. Innovative Forms of Citizen Participation at the Fringe of the Formal Planning System. Urban Plan. 2019, 4, 7-18. [CrossRef] 
11. Gaventa, J.; Barrett, G. Mapping the Outcomes of Citizen Engagement. World Dev. 2012, 40, 2399-2410. [CrossRef]

12. Zysk, E.; Dawidowicz, A.; Źróbek, S.; Źróbek, R. The concept of a geographic information system for the identification of degraded urban areas as a part of the land administration system-A Polish case study. Cities 2020, 96, 102423. [CrossRef]

13. Damurski, Ł.; Oleksy, M. Communicative and participatory paradigm in the European territorial policies. A discourse analysis. Eur. Plan. Stud. 2018, 26, 1471-1492. [CrossRef]

14. Wang, H.; Shen, Q.; Tang, B. GIS-Based Framework for Supporting Land Use Planning in Urban Renewal: Case Study in Hong Kong. J. Urban Plan. Dev. 2015, 141, 05014015. [CrossRef]

15. Brown, G.; Raymond, C.M. Methods for identifying land use conflict potential using participatory mapping. Landsc. Urban Plan. 2014, 122, 196-208. [CrossRef]

16. Fürst, C.; Opdam, P.; Inostroza, L.; Luque, S. Evaluating the role of ecosystem services in participatory land use planning: Proposing a balanced score card. Landsc. Ecol. 2014, 29, 1435-1446. [CrossRef]

17. Hersperger, A.M.; Franscini, M.P.G.; Kübler, D. Actors, Decisions and Policy Changes in Local Urbanization. Eur. Plan. Stud. 2014, 22, 1301-1319. [CrossRef]

18. von der Dunk, A.; Grêt-Regamey, A.; Dalang, T.; Hersperger, A.M. Defining a typology of peri-urban land-use conflicts-A case study from Switzerland. Landsc. Urban Plan. 2011, 101, 149-156. [CrossRef]

19. Martínez, M. The Citizen Participation of Urban Movements in Spatial Planning: A Comparison between Vigo and Porto. Int. J. Urban Reg. Res. 2011, 35, 147-171. [CrossRef]

20. Bourgoin, J.; Castella, J.C.; Pullar, D.; Lestrelin, G.; Bouahom, B. Toward a land zoning negotiation support platform: “Tips and tricks" for participatory land use planning in Laos. Landsc. Urban Plan. 2012, 104, 270-278. [CrossRef]

21. Meilvang, M.L.; Carlsen, H.B.; Blok, A. Methods of engagement: On civic participation formats as composition devices in urban planning. Eur. J. Cult. Political Sociol. 2018, 5, 12-41. [CrossRef]

22. Eiter, S.; Vik, M.L. Public participation in landscape planning: Effective methods for implementing the European Landscape Convention in Norway. Land Use Policy 2015, 44, 44-53. [CrossRef]

23. Kopáček, M. Civic Engagement in the Process of Land Use Planning: Case Study of Small Municipalities in the Czech Republic. Geogr. Cassoviensis 2019, 13, 36-52. [CrossRef]

24. Chabot, M.; Duhaime, G. Land-use planning and participation. Habitat Int. 1998, 22, 429-447. [CrossRef]

25. Kyttä, M.; Broberg, A.; Haybatollahi, M.; Schmidt-Thomé, K. Urban happiness: Context-sensitive study of the social sustainability of urban settings. Environ. Plan. B Plan. Des. 2015, 43, 34-57. [CrossRef]

26. Golobiĉ, M.; Marusîî, I. Developing an Integrated Approach for Public Participation: A Case of Land-Use Planning in Slovenia. Environ. Plan. B Plan. Des. 2007, 34, 993-1010. [CrossRef]

27. Nunbogu, A.M.; Korah, P.I.; Cobbinah, P.B.; Poku-Boansi, M. Doing it 'ourselves': Civic initiative and self-governance in spatial planning. Cities 2018, 74, 32-41. [CrossRef]

28. Brown, G.; Sanders, S.; Reed, P. Using public participatory mapping to inform general land use planning and zoning. Landsc. Urban Plan. 2018, 177, 64-74. [CrossRef]

29. Glackin, S.; Dionisio, M.R. 'Deep engagement' and urban regeneration: Tea, trust, and the quest for co-design at precinct scale. Land Use Policy 2016, 52, 363-373. [CrossRef]

30. Eshuis, J.; Klijn, E.H.; Braun, E. Place marketing and citizen participation: Branding as strategy to address the emotional dimension of policy making? Int. Rev. Adm. Sci. 2014, 80, 151-171. [CrossRef]

31. Koontz, T.M.; Newig, J. From Planning to Implementation: Top-Down and Bottom-Up Approaches for Collaborative Watershed Management. Policy Stud. J. 2014, 42, 416-442. [CrossRef]

32. Nenko, A.; Parkins, J.R.; Reed, M.G.; Sinclair, A.J. Rethinking Effective Public Engagement in Sustainable Forest Governance. Soc. Nat. Resour. 2019, 32, 1383-1398. [CrossRef]

33. Bąkowska-Waldmann, E.; Kaczmarek, T. The Use of Geo-Questionnaire in Spatial Planning. Int. J. E Plan. Res. 2019, 8, 45-67. [CrossRef]

34. Martinelli, M.A.; Achcar, J.A.; Machado Hoffmann, W.A. Cidades inteligentes e humanas: Percepção local e aderência ao movimento que humaniza projetos de smart cities. Rev. Tecnol. E Soc. 2020, 16. [CrossRef]

35. Henry, A.D.; Lubell, M.; McCoy, M. Belief Systems and Social Capital as Drivers of Policy Network Structure: The Case of California Regional Planning. J. Public Adm. Res. Theory 2011, 21, 419-444. [CrossRef]

36. Santos, B. Improving Urban Planning Information, Transparency and Participation in Public Administrations. Int. J. E Plan. Res. 2017, 6, 58-75. [CrossRef]

37. Nared, J.; Razpotnik Visković, N.; Cremer-Schulte, D.; Brozzi, R.; Cortines Garcia, F. Achieving sustainable spatial development in the Alps through participatory planning. Acta Geogr. Slov. 2015, 55. [CrossRef]

38. Häkli, J.; Kallio, K.P.; Ruokolainen, O. A Missing Citizen? Issue Based Citizenship in City-Regional Planning. Int. J. Urban Reg. Res. 2019. [CrossRef]

39. Eshkol, B.; Eshkol, A. Participatory planning in Israel: From theory to practice. J. Place Manag. Dev. 2017, 10, 213-239. [CrossRef]

40. Tudor, C.A.; Iojă, I.C.; Pătru-Stupariu, I.; Nită, M.R.; Hersperger, A.M. How successful is the resolution of land-use conflicts? A comparison of cases from Switzerland and Romania. Appl. Geogr. 2014, 47, 125-136. [CrossRef]

41. Kahila-Tani, M.; Broberg, A.; Kyttä, M.; Tyger, T. Let the Citizens Map-Public Participation GIS as a Planning Support System in the Helsinki Master Plan Process. Plan. Pract. Res. 2016, 31, 195-214. [CrossRef] 
42. Curry, N. Community Participation in Spatial Planning: Exploring Relationships between Professional and Lay Stakeholders. Local Gov. Stud. 2012, 38, 345-366. [CrossRef]

43. Blicharska, M.; Angelstam, P.; Antonson, H.; Elbakidze, M.; Axelsson, R. Road, forestry and regional planners' work for biodiversity conservation and public participation: A case study in Poland's hotspot regions. J. Environ. Plan. Manag. 2011, 54, 1373-1395. [CrossRef]

44. Hofmann, M.; Westermann, J.R.; Kowarik, I.; van der Meer, E. Perceptions of parks and urban derelict land by landscape planners and residents. Urban For. Urban Green. 2012, 11, 303-312. [CrossRef]

45. Hewitt, R.; Escobar, F. The territorial dynamics of fast-growing regions: Unsustainable land use change and future policy challenges in Madrid, Spain. Appl. Geogr. 2011, 31, 650-667. [CrossRef]

46. Mierzejewska, L. Sustainable Development of a City: Systemic Approach. Probl. Ekorozw. Probl. Sustain. Dev. 2017, 12, 71-78.

47. Shaker, R.R.; Sirodoev, I.G. Assessing sustainable development across Moldova using household and property composition indicators. Habitat Int. 2016, 55, 192-204. [CrossRef]

48. Brown, G.; Strickland-Munro, J.; Kobryn, H.; Moore, S.A. Stakeholder analysis for marine conservation planning using public participation GIS. Appl. Geogr. 2016, 67, 77-93. [CrossRef]

49. Han, Y.; Huang, Q.; He, C.; Fang, Y.; Wen, J.; Gao, J.; Du, S. The growth mode of built-up land in floodplains and its impacts on flood vulnerability. Sci. Total Environ. 2020, 700, 134462. [CrossRef] [PubMed]

50. López-Martínez, F.; Pérez-Morales, A.; Illán-Fernández, J.E. Are local administrations really in charge of flood risk management governance? The Spanish Mediterranean coastline and its institutional vulnerability issues. J. Environ. Plan. Manag. 2020, 63, 257-274. [CrossRef]

51. Chiodelli, F.; Moroni, S. Corruption in land-use issues: A crucial challenge for planning theory and practice. Town Plan. Rev. 2015, 86, 437-455. [CrossRef]

52. Brown, G.; Kelly, M.; Whitall, D. Which 'public'? Sampling effects in public participation GIS (PPGIS) and volunteered geographic information (VGI) systems for public lands management. J. Environ. Plan. Manag. 2014, 57, 190-214. [CrossRef]

53. David, N.P.; Buchanan, A. Planning Our Future: Institutionalizing Youth Participation in Local Government Planning Efforts. Plan. Theory Pract. 2020, 21, 9-38. [CrossRef]

54. Esmaeilpoorarabi, N.; Yigitcanlar, T.; Kamruzzaman, M.; Guaralda, M. How can an enhanced community engagement with innovation districts be established? Evidence from Sydney, Melbourne and Brisbane. Cities 2020, 96, 102430. [CrossRef]

55. Bjärstig, T.; Thellbro, C.; Stjernström, O.; Svensson, J.; Sandström, C.; Sandström, P.; Zachrisson, A. Between protocol and reality-Swedish municipal comprehensive planning. Eur. Plan. Stud. 2017, 26, 35-54. [CrossRef]

56. Blomley, N. Land use, planning, and the "difficult character of property". Plan. Theory Pract. 2017, 18, 351-364. [CrossRef]

57. Delitheou, V.; Bakogiannis, E.; Kyriakidis, C. Urban planning: Integrating smart applications to promote community engagement. Heliyon 2019, 5, e01672. [CrossRef]

58. Martinaityte, I.; Unsworth, K.L.; Sacramento, C.A. Is the project 'mine' or 'ours'? A multilevel investigation of the effects of individual and collective psychological ownership. J. Occup. Organ. Psychol. 2020, 93, 302-327. [CrossRef]

59. Horst, C.; Erdal, M.B.; Jdid, N. The "good citizen": Asserting and contesting norms of participation and belonging in Oslo. Ethn. Racial Stud. 2020, 43, 76-95. [CrossRef]

60. Afzalan, N.; Muller, B. Online Participatory Technologies: Opportunities and Challenges for Enriching Participatory Planning. J. Am. Plan. Assoc. 2018, 84, 162-177. [CrossRef]

61. Kaczmarek, T.; Wójcicki, M. Participation in Public Consultations on Spatial Planning Documents. The Case of Poznań City. Quaest. Geogr. 2016, 35, 71-81. [CrossRef]

62. Brown, G.; Kyttä, M. Key issues and research priorities for public participation GIS (PPGIS): A synthesis based on empirical research. Appl. Geogr. 2014, 46, 122-136. [CrossRef]

63. Karimi, A.; Brown, G.; Hockings, M. Methods and participatory approaches for identifying social-ecological hotspots. Appl. Geogr. 2015, 63, 9-20. [CrossRef]

64. Wolf, I.D.; Wohlfart, T.; Brown, G.; Lasa, A.B. The use of public participation GIS (PPGIS) for park visitor management: A case study of mountain biking. Tour. Manag. 2015, 51, 112-130. [CrossRef]

65. Zolkafli, A.; Brown, G.; Liu, Y. An Evaluation of the Capacity-building Effects of Participatory GIS (PGIS) for Public Participation in Land Use Planning. Plan. Pract. Res. 2017, 32, 385-401. [CrossRef]

66. Czepkiewicz, M.; Jankowski, P.; Młodkowski, M. Geo-questionnaires in urban planning: Recruitment methods, participant engagement, and data quality. Cartogr. Geogr. Inf. Sci. 2017, 44, 551-567. [CrossRef]

67. Hendl, J.; Remr, J. Metody Výzkumu a Evaluace; Portál: Prague, Czech Republic, 2017; pp. 137-169.

68. Czech Statistical Office-Public Database. Available online: https://vdb.czso.cz/vdbvo2/faces/en/index.jsf (accessed on 18 April 2019).

69. Thomas, E.; Riley, M.; Spees, J. Knowledge flows: Farmers' social relations and knowledge sharing practices in 'Catchment Sensitive Farming'. Land Use Policy 2020, 90, 104254. [CrossRef]

70. Aitken, M. A three-dimensional view of public participation in Scottish land-use planning: Empowerment or social control? Plan. Theory 2010, 9, 248-264. [CrossRef]

71. Castella, J.C.; Bourgoin, J.; Lestrelin, G.; Bounthanom, B. A model of the science-practice-policy interface in participatory land-use planning: Lessons from Laos. Landsc. Ecol. 2014, 29, 1095-1107. [CrossRef] 
72. Rashidfarokhi, A.; Yrjänä, L.; Wallenius, M.; Toivonen, S.; Ekroos, A.; Viitanen, K. Social sustainability tool for assessing land use planning processes. Eur. Plan. Stud. 2018, 26, 1269-1296. [CrossRef]

73. Lamker, C. Leadership roles in local land-use planning for noise control. Town Plan. Rev. 2019, 90, 275-297. [CrossRef]

74. Arciniegas, G.; Janssen, R. Spatial decision support for collaborative land use planning workshops. Landsc. Urban Plan. 2012, 107, 332-342. [CrossRef] 